\title{
ANALISIS PENGELOLAAN KELAS UNTUK MENCIPTAKAN IKLIM KELAS YANG KONDUSIF DI KELAS IV SDN ARGOPENI TAHUN AJARAN 2020/2021
}

\author{
Arina Ati Khusana1, Suhartono², Rokhmaniyah ${ }^{3}$ \\ Universitas Sebelas Maret \\ arinakhusana@gmail.com
}

\section{Article History}

accepted 30/8/2021

\begin{abstract}
:
The objectives of the study were to explain classroom management and classroom atmosphere, to describe the constraints, and to analyze factors influencing classroom management in creating conducive atmosphere at fourth grade of SDN Argopeni. It was qualitative research method. The subjects were teachers and students. The results indicated that: (1) class management consisted of being role models in religion, being a role model for good behavior, arranging the seat of students, having audible volume and voice intonation, (e) speaking straightforward, accommodating the lesson subject to students' abilities, creating orderliness, providing reinforcement and feedback on the responses and students learning outcomes, encouraging and appreciating students asking questions and delivering opinions, wearing modestly-dressed, explaining the syllabus, and starting and ending the learning on time. A conducive atmosphere was proven by having fun and exciting learning, having effective class organization, the teacher as a mentor, developing learning, managing the classroom, providing services and learning activities, and using media. The constraints of classroom management were the Covid-19 pandemic; (3) the factors influencing classroom management were the students and the teacher. It concludes that the teachers have applied classroom management in creating conducive atmosphere.
\end{abstract}

Keywords: classroom management, classroom atmosphere, conducive

\begin{abstract}
Abstrak:
Tujuan penelitian ini adalah menjelaskan pengelolaan kelas dan iklim kelas, mendeskripsikan kendala, dan menganalisis faktor yang memengaruhi pengelolaan kelas untuk menciptakan iklim kelas yang kondusif di kelas IV SDN Argopeni. Penelitian ini menggunakan metode penelitian kualitatif. Subjek penelitian adalah guru dan peserta didik. Hasil penelitian ini pengelolaan kelas terdiri dari teladan dalam beragama, berperilaku baik, pengaturan tempat duduk, volume dan intonasi suara terdengar baik, penggunaan kata-kata lugas, penyesuaian materi dengan kemampuan belajar peserta didik, penertiban kelas, penguatan, umpan balik, motivasi peserta didik bertanya dan berpendapat, berpakaian sopan, penjelasan silabus, memulai dan mengakhiri pembelajaran tepat waktu. Iklim kelas yang kondusif karena pembelajaran menyenangkan, organisasi kelas efektif, guru sebagai mentor, pengembangan pembelajaran, pengelolaan kelas menyeluruh, terdapat layanan belajar, serta penggunaan media pembelajaran. Kendala kelas ini disebabkan pandemi Covid-19. Faktor yang memengaruhi berasal dari guru dan peserta didik. Kesimpulan penelitian ini adalah guru sudah melaksanakan pengelolaan kelas untuk menciptakan iklim kelas yang kondusif.
\end{abstract}

Kata kunci: pengelolaan kelas, iklim kelas, kondusif 


\section{PENDAHULUAN}

Pendidikan ialah bagian paling penting dalam pembangunan di setiap negara. Adanya pendidikan negara dapat melakukan peningkatan kualitas sumber daya manusia untuk menyanggupi tuntutan perkembangan zaman pada abad ke-21. Indonesia sebagai negara berkembang mempunyai sistem pendidikan nasional yang dicantumkan pada undang-undang. Pada Undang-Undang RI Nomor 20 Tahun 2003 terdapat definisi bahwa "Sistem pendidikan nasional adalah keseluruhan komponen pendidikan yang saling terkait secara terpadu untuk mencapai tujuan pendidikan nasional".

Inti dari pelaksanaan pendidikan adalah pembelajaran. Pembelajaran merupakan proses komunikasi secara dua arah yaitu antara guru yang mengajar dengan peserta didik yang belajar (Djabidi, 2016: 23). Slameto memberikan pengertian belajar sebagai kegiatan individu yang berproses dan berusaha untuk mendapatkan perubahan perilaku yang baru secara menyeluruh sebagai hasil pengalaman individu tersebut yang telah melakukan interaksi dengan lingkungan (Wiyani, 2017: 17). Sedangkan mengajar menurut Hamalik adalah sebagai usaha pengorganisasian lingkungan untuk menciptakan kondisi belajar yang memadai bagi peserta didik (Djabidi, 2016: 9).

Pembelajaran yang berhasil ditentukan oleh guru. Seperti yang disampaikan oleh Delceva (2014: 52) bahwa "The teacher, being the key for the teaching process, should be able to establish a positive school atmosphere". Saat pembelajaran berlangsung, guru tidak hanya berperan sebagai penyampai pengetahuan atau mengajar saja. Lebih dari itu, guru harus mampu menguasai delapan keterampilan dasar mengajar. Salah satunya adalah mengelola kelas yang dapat menciptakan pembelajaran yang kondusif.

Pengelolaan kelas menurut Djamarah dan Zain adalah keterampilan guru untuk menciptakan dan memelihara kondisi belajar yang optimal dan mengembalikan kondisi jika di dalam proses belajar mengajar terjadi gangguan (Khobir, Yusuf \& Alhusaini, 2019: 196). Chandra menyatakan bahwa "...teacher and student behavior are directly linked with the concept of classroom management" (2015: 13). Artinya, guru dan peserta didik saling berkaitan dengan adanya pengelolaan kelas.

Di dalam pembelajaran terdapat komunikasi antara guru dengan peserta didik secara dua arah dan aktif sehingga saling berkaitan untuk menciptakan iklim kelas yang kondusif. Saat guru mengajar, sedemikian rupa kelas dapat diatur agar tercipta lingkungan belajar yang baik sehingga peserta didik termotivasi belajar. Apabila lingkungan belajar di kelas tidak kondusif, peserta didik menjadi tidak nyaman bahkan dapat menimbulkan masalah seperti membuat kegaduhan di kelas.

Di dalam penciptaan iklim kelas yang kondusif guru perlu mengadakan pengelolaan kelas secara maksimal. Hal ini sejalan dengan penelitian di Gugus Bungong Seulang Kecamatan Syiah Kuala Kota Banda Aceh yang mendapatkan hasil bahwa guru yang kreatif dalam mengelola kelas dapat mengembangkan iklim kelas yang kondusif sehingga memberikan rasa senang, nyaman, mengasyikkan, akrab, dan bersemangat kepada peserta didik (Mursalin, Sulaiman, \& Nurmasyitah, 2017: 113).

Untuk menciptakan iklim belajar yang tepat guru perlu memahami konsep pengelolaan kelas secara menyeluruh. Pengaturan ruang belajar dapat meliputi kegiatan mengatur tempat duduk peserta didik, mengatur media pembelajaran, mengatur tanaman dan tumbuh-tumbuhan serta pemberian aromaterapi (Wiyani, 2017, 131-156). Selain itu, pengelolaan kelas juga disesuaikan dengan karakteristik peserta didik. Adapun teori kognitif Piaget untuk peserta didik SD dengan usia $6-12$ tahun dikategorikan ke tahapan operasional konkret, oleh karena itu guru dituntut untuk melaksanakan pembelajaran dengan cara yang inovatif dan menyenangkan (Minsih \& Galih, 2018: 20).

Peserta didik SD dikelompokkan menjadi 2 yaitu kelas rendah yang terdiri atas kelas 1, 2, dan 3, serta kelas tinggi yang terdiri atas kelas 4, 5, dan 6. Karakteristik peserta didik kelas rendah berbeda dengan peserta didik kelas tinggi. Peserta didik 
kelas rendah masih perlu bimbingan dan pengawasan untuk membedakan hal baik dan hal buruk, sedangkan peserta didik kelas tinggi mulai berpikir logis untuk memahami sesuatu tetapi masih terbatas pada objek konkret (Surya, dkk., 2018: 32).

Hal yang merarik untuk diteliti adalah pengelolaan kelas oleh guru kelas empat dengan karakteristik peserta didik yang berada di masa peralihan dari kelas rendah menjadi kelas tinggi. Berdasarkan hasil observasi di enam kelas yaitu kelas IV SDN 1 Panjer, SDN 7 Kebumen, kelas IV A dan kelas IV B di SDN 5 Panjer dan SDN Argopeni pada tanggal 3 Desember 2019, ternyata 5 dari 6 guru belum mampu mengelola kelas dengan maksimal. Terdapat guru yang terlambat masuk kelas dan hanya sekedar mengajar tanpa menghiraukan iklim kelas yang tidak kondusif dengan alasan agar materi pelajaran cepat selesai. Adapun kelas yang peserta didiknya sangat pasif. Selain itu, guru kelas empat sering diutus sekolah untuk menghadiri acara di luar sekolah, namun ada pula guru yang keluar kelas untuk kepentingan pribadi. Hal ini menjadikan kelas kosong dan berkurangnya motivasi untuk belajar sehingga peserta didik dapat menimbulkan kegaduhan bahkan berlarian keluar kelas walaupun guru telah memberikan tugas.

Selain mengajar, seharusnya guru dapat memberikan pembelajaran yang menyesuaikan karakteristik peserta didik yang kemudian dapat dijadikan bahan untuk pengelolaan kelas. Pengelolaan kelas yang kurang maksimal dapat berujung pada penyesalan guru karena hasil belajar dari peserta didik tidak sesuai harapan. Oleh karenanya, penting adanya penelitian tentang pengelolaan kelas untuk menciptakan iklim kelas yang kondusif sehingga menjadi pedoman untuk meningkatkan keberhasilan guru mengelola kelas.

Berbeda dengan guru kelas IV A SDN Argopeni, Kecamatan Kebumen, Kabupaten Kebumen yang telah berhasil mengelola kelas. Jumlah peserta didik di kelas ini adalah 30 anak. Walaupun sekolah ini terletak di pinggiran kota tetapi peserta didik di kelas ini memiliki motivasi belajar yang tinggi. Tidak kalah dengan peserta didik di kota. Terlihat saat berlangsungnya pembelajaran di kelas, peserta didik begitu aktif merespon guru yang sedang mengajar. Hal ini tentunya didukung dengan pengelolaan kelas yang mumpuni oleh guru kelas misalnya menyediakan kelas yang nyaman, formasi tempat duduk peserta didik yang tidak monoton dan guru sering mengajak peserta didik berinteraksi dengan aktif sehingga iklim kelas menjadi kondusif.

Tujuan penelitian ini adalah: (1) menjelaskan pengelolaan kelas untuk menciptakan iklim kelas yang kondusif di kelas IV SDN Argopeni; (2) mendeskripsikan kendala pengelolaan kelas untuk menciptakan iklim kelas yang kondusif di kelas IV SDN Argopeni, Desa Argopeni; (3) menganalisis faktor-faktor yang memengaruhi pengelolaan kelas untuk menciptakan iklim kelas yang kondusif di kelas IV SDN Argopeni.

\section{METODE}

Penelitian ini dilaksanakan di SDN Argopeni sejak bulan November 2019 sampai dengan bulan November 2020. Metode penelitian yang digunakan adalah kualitatif dengan pendekatan studi kasus. Subjek penelitian ini adalah guru dan peserta didik kelas IV. Data yang diambil untuk penelitian ini adalah data kualitatif. Sumber data penelitian ini terdiri dari tempat dan peristiwa, informan, serta dokumen. Informan adalah guru kelas IV, peserta didik kelas IV, dan kepala sekolah.

Teknik pengambilan subjek adalah purposive sampling. Teknik pengumpulan data terdiri dari observasi, wawancara, dan analisis dokumen. Teknik uji validitas data penelitian ini adalah triangulasi sumber. Teknik analisis data penelitian ini adalah berdasarkan model analisis data menurut Miles dan Huberman (Sugiono, 2015: 337345) yang terdiri dari reduksi data, penyajian data, dan verifikasi. Tahapan penelitian ini meliputi: (1) tahap pra lapangan; (2) tahap pekerjaan lapangan; (3) tahap analisis data; serta (4) tahap validitas data. 


\section{HASIL DAN PEMBAHASAN}

Berdasarkan observasi, wawancara, dan analisis dokumen dari Oktober sampai November 2020, guru telah melakukan pengelolaan kelas untuk menciptakan iklim kelas yang kondusif. Guru menghayati dan mengamalkan ajaran agama yang dianutnya, serta mewujudkan kerukunan dalam kehidupan bersama. Guru menunjukkan teladan dalam berperilaku baik seperti jujur, disiplin, tanggung jawab, peduli, responsif, proaktif, dan solutif. Guru berpakaian sopan, bersih dan rapi. Hal ini sesuai pernyataan Palunga dan Marzuki bahwa guru dituntut menjadi teladan bagi peserta didik melalui perkataan, menunjukkan sikap, tingkah laku, dan perilaku yang baik (2017: 112). Guru mengatur tempat duduk peserta didik dan sumber daya lain sesuai tujuan dan karakteristik pembelajaran. Berdasarkan pernyataan Wiyani bahwa tempat duduk dapat memengaruhi peserta didik mencapai keberhasilan belajar (2017: 131). Volume dan intonasi suara guru saat pembelajaran dapat didengar baik peserta didik. Guru menggunakan kata-kata yang santun, lugas dan mudah dimengerti peserta didik. Hal ini sesuai pendapat Wiyani bahwa untuk menyampaikan materi, guru menggunakan variasi intonasi suara, volume, nada, kecepatan, isi pembicaraan, dan penggunaan bahasa yang tepat (2017: 82). Guru menyesuaikan materi pelajaran dengan kecepatan dan kemampuan belajar peserta didik. Penyesuaian ini sebagai keluwesan guru untuk menciptakan iklim kelas yang kondusif. Hal ini sesuai dengan pernyataan Wiyani bahwa keluwesan guru dapat mengganti metode mengajar yang selaras dengan materi pelajaran dan kebutuhan, kecepatan, serta kemampuan peserta didik (2017: 83). Guru menciptakan ketertiban, kedisiplinan, kenyamanan, dan keselamatan selama pembelajaran. Guru memberikan penguatan dan umpan balik terhadap respons dan hasil belajar peserta didik selama pembelajaran secara verbal dan nonverbal. Sesuai dengan pernyataan Wiyani bahwa dua jenis penguatan yaitu penguatan verbal yang berbentuk ucapan dan penguatan nonverbal yang berbentuk gerakan fisik (2017: 36). Guru mendorong dan menghargai peserta didik yang bertanya dan berpendapat agar dapat menilai tingkat pemahaman mereka. Hal ini sesuai dengan pernyataan Royani dan Muslim bahwa melalui bertanya, peserta didik dapat mengetahui makna suatu hal atau suatu masalah untuk menentukan solusi yang tepat (2014: 12). Agar pengelolaan kelas dapat berlangsung dinamis, guru harus mampu dan bersedia menghargai pendapat, saran dan gagasan dari peserta didik (Zahroh, 2015: 187). Guru menyusun silabus sesuai dengan Peraturan Menteri Pendidikan dan Kebudayaan Republik Indonesia Nomor 22 tahun 2016 tentang Standar Proses Pendidikan Dasar dan Menengah. Di awal semester guru tidak menjelaskan silabus namun hanya menjelaskan tema selama semester tersebut. Guru memulai dan mengakhiri pembelajaran tepat waktu untuk menekankan disiplin diri. Hal ini sesuai dengan pendapat Wiyani bahwa kegiatan membuka pelajaran dilakukan agar mental dan perhatian peserta didik terpusat pada pembelajaran, sedangkan kegiatan menutup pelajaran dilakukan agar memberikan gambaran utuh pelajaran, mengetahui pencapaian peserta didik dan keberhasilan mengajar guru (2017: 40-41). Dua belas cara pengelolaan kelas yang telah dilakukan guru tersebut memenuhi Peraturan Menteri Pendidikan dan Kebudayaan Republik Indonesia Nomor 22 tahun 2016 tentang Standar Proses Pendidikan Dasar dan Menengah.

Iklim kelas yang kondusif terbukti dengan pemenuhan indikator berikut: (1) pembelajaran bersifat menyenangkan dan mengasyikkan; (2) adanya organisasi kelas efektif; (3) guru sebagai mentor; (4) guru bersama peserta didik bertanggung jawab mengembangkan pembelajaran; (5) guru mengelola kelas secara menyeluruh; (6) guru memberikan layanan dan kegiatan belajar; serta (7) menggunakan media saat mengajar. Iklim kelas ini sesuai pendapat Hermawan bahwa untuk menciptakan iklim kelas yang kondusif, harus mencakup beberapa aspek yaitu: (1) menyenangkan dan mengasyikkan; (2) mencerdaskan dan menguatkan; (3) pengelolaan peserta didik; (4) pengelolaan materi pembelajaran; (5) pengelolaan sumber belajar; (6) layanan dan 
kegiatan belajar; (7) guru sebagai mentor; serta (8) menggunakan berbagai media (Djabidi, 2016: 119-120). Berbagai layanan dan kegiatan ini menurut Mulyasa: (1) adabya pilihan kepada peserta didik yang cepat maupun lambat untuk melaksanakan tugas; (2) mengadakan remedial; (3) organisasi kelas efektif; (4) antarpeserta didik maupun antara peserta didik dan guru saling menghargai; (5) peserta didik ikut merencanakan pembelajaran; (6) guru bersama peserta didik bertanggung jawab mengembangkan pembelajaran; serta (7) adanya sistem evaluasi belajar (2018: 2122).

Terdapat kendala dalam pengelolaan kelas untuk menciptakan iklim kelas yang kondusif. Kendala yang terjadi dikarenakan pandemi Covid-19 yang menyebabkan pembelajaran tidak dapat dilakukan tatap muka secara langsung agar virus tidak menyebar di lingkungan sekolah. Walaupun demikian, guru tetap mengusahakan pengelolaan kelas dengan maksimal agar iklim kelas kondusif. Kemudian guru mengadakan pembelajaran daring menggunakan WhatsApp, Zoom dan Google Classroom. Sesekali guru berkunjung ke rumah peserta didik yang telah dikelompokkan berdasarkan perdukuhan dengan izin pemerintah setempat dan menaati protokol kesehatan. Jika terdapat peserta didik yang sulit memahami pesan guru, maka guru segera mengetik ulang dengan kata yang lebih mudah dipamahi. Kendala lainnya seperti: (1) fasilitas belajar di rumah yang seadanya; (2) ada peserta didik yang kesulitan mengikuti pembelajaran dan mengerjakan tugas karena tidak punya handphone; (3) saat belajar kelompok, peserta didik jarang menggunakan tempat duduk dan meja belajar sehingga mereka duduk di lantai; (4) pembelajaran sangat bergantung pada handphone dan internet; serta (5) sarana dan prasarana kelas yang lengkap namun kurang dimaksimalkan penggunaannya oleh guru karena tidak sesuai dengan keadaan di masa pandemi.

Faktor yang memengaruhi pengelolaan kelas untuk menciptakan iklim kelas yang kondusif berasal dari guru dan peserta didik. Faktor dari guru adalah lingkungan kelas dan metode pembelajaran. Selama pandemi ini guru tidak dapat menggunakan ruangan kelas, kemudian beralih memanfaatkan media sosial agar pembelajaran terus berjalan. Metode pembelajaran yang digunakan adalah ceramah, tanya jawab, diskusi, demonstrasi dan disesuaikan dengan keadaan. Faktor tersebut sesuai pernyataan Winataputra bahwa faktor yang mendukung pengelolaan kelas terdiri dari lingkungan fisik atau lingkungan kelas dan metode pembelajaran yang digunakan seperti ceramah, tanya jawab, diskusi, demonstrasi, sosiodrama, dan karyawisata (Djabidi, 2016: 46-47). Faktor dari peserta didik adalah faktor internal dan eksternal. Faktor internal peserta didik meliputi aspek fisiologi yang berkaitan dengan kondisi umum jasmani mereka yang menandakan tingkat kesehatan dan kebugaran, serta aspek psikologis meliputi intelegensi, sikap, bakat, minat dan motivasi. Peserta didik mengikuti pembelajaran dalam keadaan sehat dan pembelajaran yang menyenangkan karena guru rajin memotivasi. Faktor eksternal peserta didik meliputi lingkungan sosial dan lingkungan nasional. Selama ini peserta didik tidak belajar di ruangan kelas tetapi di rumah yang menjadikan mereka dan orang tua semakin melek teknologi. Guru memberikan referensi sumber belajar buku tematik, LKS, link Youtube, video pembelajaran, koran, dan majalah. Faktor tersebut sesuai pernyataan Djabidi bahwa faktor yang memengaruhi pengelolaan kelas meliputi faktor internal dan faktor eksternal peserta didik (2016: 53-55).

\section{SIMPULAN}

Guru kelas IV SDN Argopeni berhasil melakukan pengelolaan kelas untuk menciptakan iklim kelas yang kondusif sebelum dan selama masa pandemi Covid-19. Pengelolaan kelas dilakukan dengan cara menjadi teladan dalam beragama, berperilaku baik, pengaturan tempat duduk, volume dan intonasi suara terdengar baik, penggunaan kata-kata lugas, penyesuaian materi dengan kemampuan belajar peserta 
didik, penertiban kelas, penguatan, umpan balik, memotivasi peserta didik bertanya dan berpendapat, berpakaian sopan, memulai dan mengakhiri pembelajaran tepat waktu. Iklim kelas yang kondusif terbukti dengan pembelajaran yang menyenangkan, organisasi kelas yang efektif, guru sebagai mentor, pengembangan pembelajaran, pengelolaan kelas menyeluruh, terdapat layanan belajar, serta penggunaan media pembelajaran. Kendala kelas ini disebabkan pandemi sehingga pembelajaran tidak dapat dilakukan di ruangan kelas. Walaupun demikian, guru tetap berusaha mengelola kelas dengan maksimal dengan mengadakan pembelajaran daring sehingga peserta didik dan orang tua mereka semakin melek teknologi. Faktor yang memengaruhi pengelolaan kelas berasal dari guru dan peserta didik.

Implikasi penelitian ini yaitu dapat dijadikan bahan pertimbangan guru dan kepala sekolah untuk merencanakan pengelolaan kelas sehingga menciptakan iklim kelas yang kondusif. Selain itu, orang tua sebaiknya menemani anaknya belajar di rumah. Bagi peneliti lain dapat melaksanakan penelitian dengan tema yang serupa namun variabel atau indikator dapat dibahas lebih dalam contohnya hasil belajar peserta didik.

\section{DAFTAR PUSTAKA}

Chandra, R. (2015). Classroom Management for Effective Teaching (Versi elektronik). International Journal of Education and Psychological Research (IJEPR), 4 (4), 13-15. Diperoleh 19 November 2019, dari https://www.researchgate.net.

Delceva, J. (2014). Classroom Management. International Journal of Cognitive Research in Science, Engineering and Education (IJCRSEE), 2 (1), 51-56. Diperoleh 9 Desember 2019, dari https://www.ijcrsee.com.

Depdiknas. (2003). Undang-Undang Republik Indonesia Nomor 20 Tahun 2003 Tentang Sistem Pendidikan Nasional. Jakarta: Departemen Pendidikan Nasional.

Djabidi, F. (2016). Manajemen Pengelolaan Kelas: Upaya Peningkatan Strategi dan Kualitas dalam Pembelajaran. Malang: Madani.

Khobir, K., Yusuf, M., \& Alhusaini, A. (2019). Keterampilan Guru dalam Mengelola Kelas untuk Anak Berkebutuhan Khusus. Jurnal Manajemen, Kepemimpinan, dan Supervisi Pendidikan, 4 (2), 194-201. Diperoleh 19 November 2019, dari https://jurnal.univpgri-palembang.ac.id.

Minsih \& Galih, A. (2018). Peran Guru dalam Pengelolaan Kelas. Jurnal Profesi Pendidikan Dasar, 5 (1), 20-27. Diperoleh 9 Desember 2019, dari http://journals.ums.ac.id.

Mulyasa, H. E. (2018). Manajemen Pendidikan Karakter. Cetakan keenam. Jakarta: PT Bumi Aksara.

Mursalin, Sulaiman, \& Nurmasyitah. (2017). Peran Guru dalam Pelaksanaan Manajemen Kelas di Gugus Bungong Seulang Kecamatan Syiah Kuala Kota Banda Aceh. Jurnal IImiah Pendidikan Guru Sekolah Dasar, 2 (1), 105-114. Diperoleh 9 Desember 2019, dari https://www.jim.unsyiah.ac.id.

Royani, M. \& Muslim, B. (2014). Keterampilan Bertanya Siswa SMP melalui Strategi Pembelajaran Aktif Tipe Team Quiz pada Materi Segi Empat. EDU-MAT Jurnal Pendidikan Matematika, 2 (1), 22-28. Diperoleh 26 September 2020, dari https://ppip.ulm.ac.id.

Palunga, R. \& Marzuki. (2017). Peran Guru dalam Pengembangan Karakter Peserta Didik di Sekolah Menengah Pertama Negeri 2 Depok Sleman. Jurnal Pendidikan Karakter, 7 (1), 109-123. Diperoleh 26 September 2020, dari https://journal.uny.ac.id.

Permendikbud. (2016). Peraturan Menteri Pendidikan dan Kebudayaan Republik Indonesia Nomor 22 Tahun 2016 tentang Standar Proses Pendidikan Dasar dan Menengah. Jakarta: Peraturan Menteri Pendidikan dan Kebudayaan. 
Sugiyono. (2015). Metode Penelitian Pendidikan: Pendekatan Kuantitatif, Kualitatif, dan $R \& D$. Cetakan ke-21. Bandung: Alfabeta.

Surya, A., Sularmi, Istiyati, S., \& Prakoso, R. F. (2018). Prosiding 1st Nasional Seminar on Elementary Education (SNPD 2018) Finding HOTS-BASED Mathematical Learning in Elementary School, hlm. 30 - 37. Surakarta: FKIP Universitas Sebelas Maret.

Wiyani, N. A. (2017). Manajemen Kelas: Teori dan Aplikasi untuk Menciptakan Kelas yang Kondusif. Cetakan kedua. Jogjakarta: Ar-Ruzz Media.

Zahroh, L. (2015). Pendekatan dalam Pengelolaan Kelas. Jurnal Tasyri', 22 (2), 175189. Diperoleh 16 September 2020, dari http://ejournal.kopertais4.or.id. 